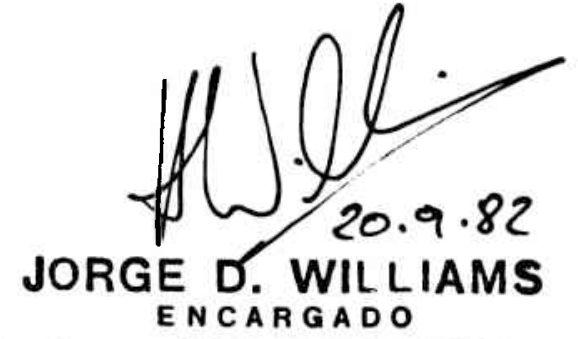

SE C C. H E R PETOLOG IA
DIV. ZOOL. VERTEBRADOS
UOSEO dO CIENCIAS MATUBALES dO LA PLATA
PASEO DE BOSQUE S/N.
1900 - LA PLATA - ARGENTINA

Journal of Herpetology, Vol. 16, No. 2, pp. 179-182, 1982 Copyright 1982 Society for the Study of Amphibians and Reptiles

\section{A New Endemic Lizard from Sierra Pie de Palo in Western Argentina}

José M. CeI, Departamento Ciencias Naturales, Universidad Nacional de Rio Cuarto, Prov. of Cordoba,
Argentina. Present address: Rancho Somuncura, Rua F. de Figueiredo, Birre, 2750 Cascais, Portugal.

Endemic herpetofaunal elements characterize the several extra-Andean or Pampean embossments extending along the Andean mountains of Argentina, from $27^{\circ}$ to $32^{\circ}$ south latitude. That endemism is in agreement with both the independent tectonic and geological history of the isolated Pampean mountains (Caminos, 1979), and the geographical and ecological barriers resulting from the paleoclimatic events of the late Pleistocene glaciation (Cei, 1980a). The Sierra Pie de Palo is a steep longitudinal Precambrian and Paleozoic relief, $60 \mathrm{~km}$ long and $30 \mathrm{~km}$ wide, from $31^{\circ} 05^{\prime}$ to $31^{\circ} 40^{\prime}$ south latitude. It rises about $30 \mathrm{~km}$ east of the easternmost precordilleran slopes, at San Juan, central Argentina (Fig. 1). A preliminary ecological and biogeographical study of that still unexplored extra-Andean embossment revealed its peculiar physiognomic features (Cei, $1980 \mathrm{~b}$ ). Three phytogeographical and faunal altitudinal zones were recognized. In the higher zone, from 2800 to $3200 \mathrm{~m}$, up to the summit, the only reptile found was a moderate-sized iguanid lizard of the genus Liolaemus. It is closely related to the Andean-Patagonian bibroni group, but is distinct from all other known taxa in significant morphological characters.

Specimens of the new species are in the Museo Zoologico, Florence, Italy (MZUF), the Museum of Natural History, University of Kansas (KU), the Instituto M. Lillo, Universidad Nacional de Tucumán, Argentina (ML) and in J. M. Cei-Diagnostic Collection (JMC-DC).

\section{Liolaemus sanjuanensis sp. nov.}

Holotype,-MZUF 26933, male, near Mogote Corralitos, Sierra Pie de Palo, $3200 \mathrm{~m}$, San Juan Province, Argentina, J. M. Cei, 11 Nov. 1980.

Paratypes. - MZUF 26934-26938, a male, two females and two juveniles; KU 187452-187454, a male, two females; FML 01016/1-2, a male, a female; JMC-DC 600-601, a male, a female. All with the same data as holotype.

Diagnosis.-A moderate-sized, slender Liolaemus, differing from other forms of the bibroni group in having larger body, distinct sexual dimorphism in head length and axilla-groin distance, different interparietal-parietal ratio, unkeeled temporal scales, a larger number of preanal pores in males and a very different coloration.

Description of the Holotype.-Body stout but elongate, with moderate hind legs, reaching the axilla. Head about $1 / 4$ body length. Rostral more than twice as wide as high. Nasal rounded, opening laterally, above and anterior to canthal ridge, contacting rostral and separated from supralabials by a very small, rectangular scale. Internasals, frontonasals and prefrontals quadrangular, smooth and symmetrically arranged. An azygous frontal; supraorbital semicircles distinct. Three-four en- 


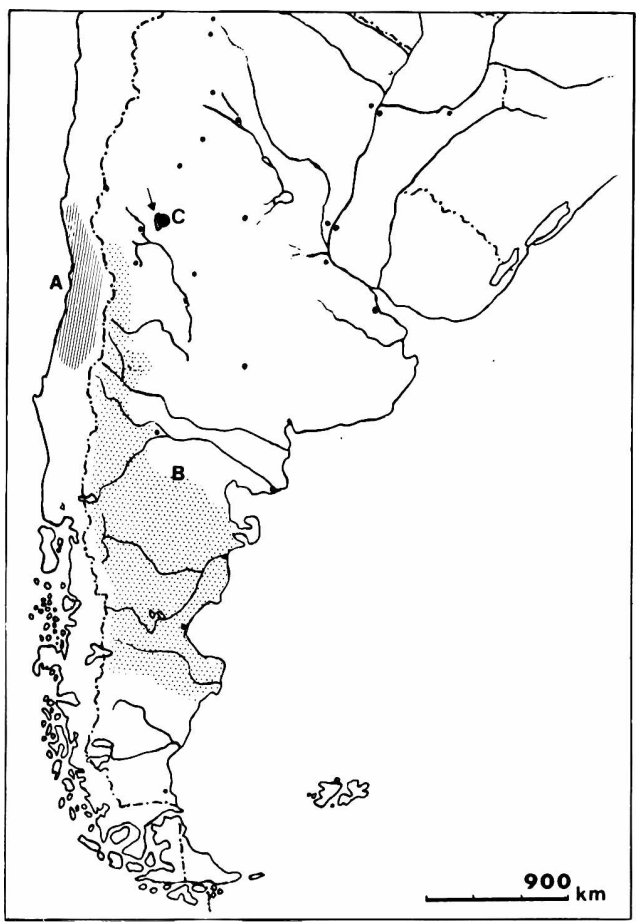

FIG. 1. Distribution of the Liolaemus bibroni complex in South America. A. Liolaemus fuscus. B. Liolaemus bibroni. C. Liolaemus sanjuanensis. The arrow indicates the isolated Sierra Pie de Palo, San Juan Province, Argentina.

larged supraoculars, medially contacting supraorbital semicircles, laterally separated from superciliaries by 2-3 rows of smaller, irregular scales. Interparietal slightly smaller than parietals, central "eye" of interparietal very small. Scales of parietal and upper temporal region smaller than parietals, faintly rough, unkeeled. A short, sharp canthal, followed by six elongate, overlapping superciliaries. A large, concave subocular separated from supralabials by a single row of enlarged scales. Temporals moderate, slightly rough, unkeeled. Ear opening transverse, bordered by three projecting scales anteriorly, by granular scales posteriorly. Six-seven enlarged, smooth supralabials; mental subtriangular; five infralabials, wider than supralabials. Eight enlarged postmental and lateral gulars. Gulars small, smooth and imbricate; no gular fold. Scales on sides of neck small, keeled and acuminate; longitudinal and transverse antehumeral folds evident. Dorsal nuchals small, imbricate and distinctly keeled. Dorsal and dorsolateral body scales acuminate, distinctly keeled, imbricate and arranged in regular longitudinal rows, becoming granular in axillary region. Ventral scales rhomboidal, imbricate, smooth and regularly arranged, equal or subequal to dorsals. Proximal caudal scales anterior to the first autotomy segment similar to dorsals on trunk above, rhomboidal and smooth below. Distal caudal scales squarish, diagonally keeled above and below.

Upper limb scales keeled, imbricate; ventral limb scales smooth, imbricate; thigh bordered by a row of enlarged scales, finely granular posteriorly. Supracarpals, supratarsals and supradigitals smooth. Ventral scales of hand and foot carinate or tricarinate; infradigital lamellae tricarinate. Scales at midbody $53 ; 15$ scales contained in head length; 19 lamellae under fourth finger; 23 lamellae under fourth toe; 5 preanal pores.

Dorsally brownish gray, with scattered very small, symmetrical, white-bordered dark spots; pileus pale brown; a lateral reddish eosin-shade on body and tail, marked on flanks with irregular, diffuse black spots. Upper tail grayish, banded with faint, darker, interrupted rings. Ventrally whitish gray, immaculate; gular region and ventral surface of tail pale gray. Groin region and ventral surface of thigh and tibia pale orange; preanal pores orange-brown.

Measurements in $\mathrm{mm}$ : snout-vent length 61 ; tail 80 ; foreleg 20 ; hind leg 31.5 ; axilla-groin distance 30

Variation.-Snout-vent length (minimum, mean $+\mathrm{SE}$, maximum): $58(58.60 \pm 0.60) 61$ in five adult males, $56(59.58 \pm 1.09) 64$ in six adult females; no significant sex difference in size. Midbody scales 52-55 in males, 52-56 in females. Snout-vent length 43 in two juvenile males. Head $1 / 4$ body length in males, $1 / 5$ body length in females. Distance from axilla to groin significantly larger in females. Interparietal always smaller than parietal in both males and females. Patterns of coloration similar to holotype in males; quite different in females, showing a paler whitish or reddish dorsal background, with three broken, parallel brownish stripes in the vertebral region. Dorsally interrupted transverse bands on tail of females. A light-bordered and dark-spotted band on flanks of females, from temporal region to groin. Pattern of dark, irregular transverse bands, white-bordered posteriorly, in some females.

Range.-Known only for the type locality.

Etymology. - The specific name refers to San Juan Province, home of this montane form.

Remarks.-Liolaemus sanjuanensis lives at about $2800-3200 \mathrm{~m}$ in the ravines and under stones on the rocky summits of the sierra. During the warmest hours of the day, from about 0900 to 1800 in the summer, it emerges from its stony shelters and forages in the surrounding Stipa bunches and other xeric-adapted associations. It is an oviparous lizard, as are the other species of the bibroni group. On 2 December 1980 a female laid five large white eggs. Contrary to Donoso's statement (1966), the closely related Andean-Patagonian $L$. bibroni is oviparous. No other iguanid 

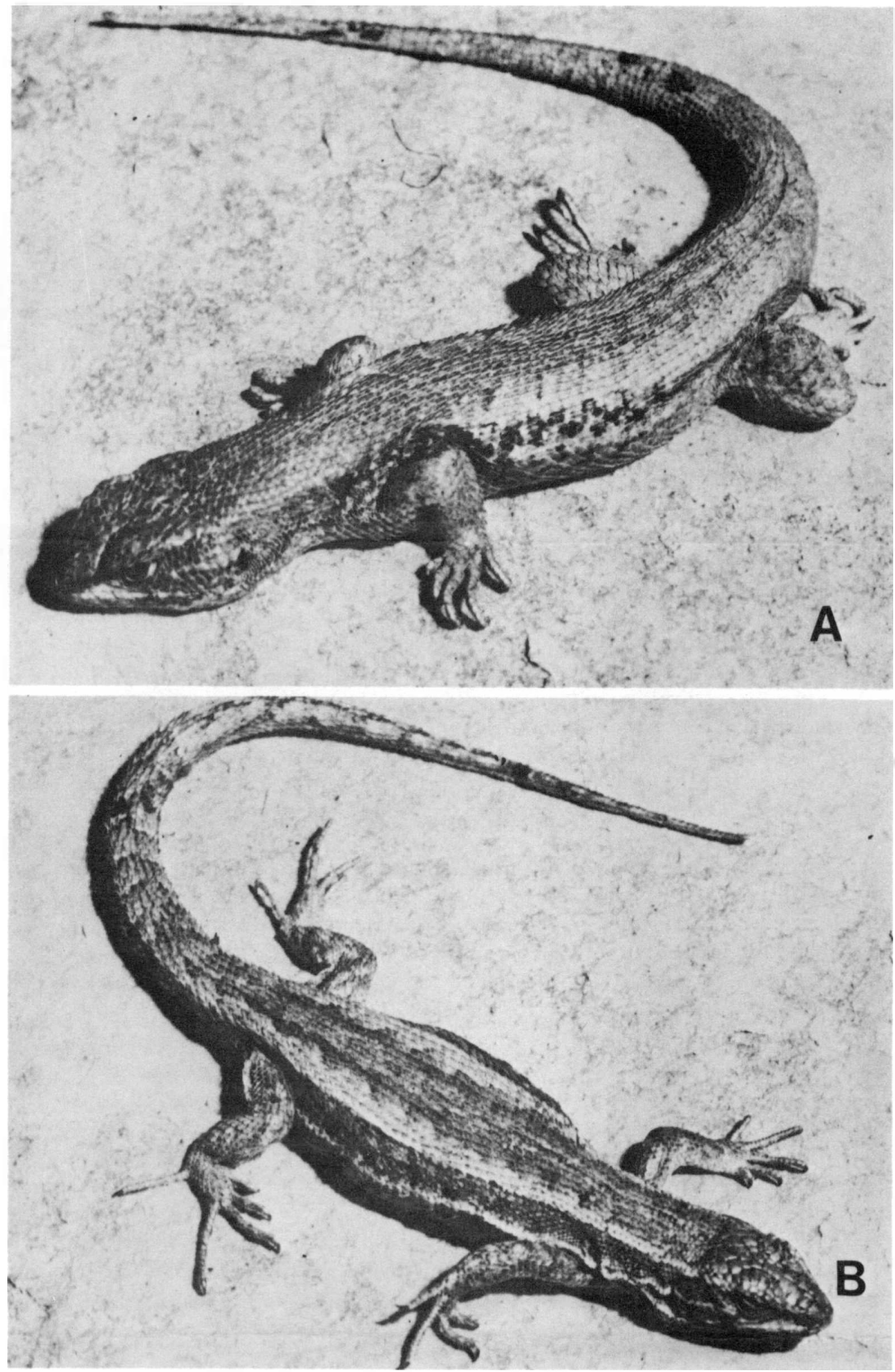

FIg. 2. A. Liolaemus sanjuanensis male from Sierra Pie de Palo, San Juan Province, Argentina. B. The same, female.

or geckonid lizards were found above $2800 \mathrm{~m}$ in the Pie de Palo mountains. Only ecdysal fragments of some unidentified colubrid snakes and a small toad of the Bufo spinulosus group were observed. In the habitat of $L$. sanjuanensis the dominant floral associations consist of Andean shrubs, such as Nassauvia axillaris, Tetraglachin. Adesmia, Baccharis, Berberis, Senecio, Opuntia hickeni, etc. Andean-Patagonian features are also emphasized by the specialized invertebrate fauna of the sierra, such as scorpions (Bothriurus burmeisteri), solpugids (Pseudocleobis andinus), spiders, tenebrionid beetles, etc. For a general discussion of this isolated montane region see Cei (1980b).

This new species can be easily distinguished from the other recognized species of the complex, L. bibroni (Bell) and L. fuscus Boulenger. Liolaemus sanjuanensis is a stouter and larger form. Snout-vent measurements in $\mathrm{mm}$ show in males $58(58.60 \pm 0.60) 61$ for 5 sanjuanensis, 45 (53.60 
$\pm 0.56) 61$ for 48 bibroni, $35.4(44.41 \pm 0.48) 51$ for 65 fuscus; in females $56(59.50 \pm 1.09) 64$ for 6 sanjuanensis, $46(51.95 \pm 1.08) 60$ for 43 bibroni and $35.2(41.43 \pm 0.44) 47.6$ for 48 fuscus. That character is significantly dissimilar in all of these forms at a $P=0.001$ or $<0.001$ (Student-Fisher Test). The snout-vent/axilla-groin ratio is also significantly dissimilar, at a $P<0.001$, in the males of all of these forms and in females of sanjuanensis and bibroni. Thus, the distance from axilla to groin supports the specific distinctiveness of sanjuanensis differing from males and females of bibroni, and also from males of fuscus. The snout-vent/head length ratio is significantly dimorphic sexually in sanjuanensis (head shorter in females), but the same is significantly dissimilar in females of sanjuanensis, bibroni and fuscus.

The interparietal, smaller than parietals in sanjuanensis, is equal to parietals in bibroni, less than one half of parietals in fuscus. Dorsal scales are slightly smaller than ventrals in bibroni, equal or subequal in sanjuanensis and fuscus. Temporal scales are unkeeled in sanjuanensis, slightly keeled in the other forms. Scales on the anterior border of ear opening are very prominent in sanjuanensis, smaller in bibroni; caudal scales are also larger and almost bristly in sanjuanensis, smaller and faintly mucronate in bibroni. Different color patterns characterize all of these species. Color dimorphism is very evident in sanjuanensis, almost nonexistent in bibroni and fuscus; the dark vertebral stripe on the tail of bibroni is absent in sanjuanensis and fuscus. Preanal pores are 5-6 in sanjuanensis, 2-4 as a rule in bibroni and fuscus.

Ecologically, both $L$. sanjuanensis and $L$. bibroni are small, cold-adapted dwellers of arid stony soils and/or bush-covered open steppe. Through its extensive Andean-Patagonian distribution $L$. bibroni ranges from sea level (Puerto Deseado, terra typica) to about $2000-3000 \mathrm{~m}$ in the Mendoza Cordillera (Cei, 1973). L. fuscus is an inhabitant of the xeromorphic sub-Andean formation and the coast steppe environments of central Chile, rarely above $1000 \mathrm{~m}$.

The origin of $L$. sanjuanensis can be related to the last Pleistocene stages of glaciation (Cei, $1980 a$ ). As the snow line and high Andean vegetation rose during the late interglacial stage, several cold-adapted herpetofaunal elements followed the retreat of high montane environments. In spite of their probable common ancestry during former glacial stages, genetically isolated populations, such as $L$. bibroni and $L$. sanjuanensis, lie now disjunct in the Andean cordilleras and in the steep, almost inaccessible Pie de Palo mountains. Their close relationships with $L$. fuscus from Chilean xeromorphic habitats are suggestive of ancient cis-transAndean patterns of distribution prior to the late events of Andean orogenesis that became a factor in creating geographic isolation in the continent.

Acknowledgments. - I wish to thank Jorge R. Zavalla and Eleodoro A. Sanchez of the Sub-Secre- taria Agricultura e Ganaderia, Government of the San Juan Province, for their support in collecting the animals used in this study. I am also greatly indebted to the late Roberto Cei of the Instituto e Museo de Ciencias Naturales, Universidad Nacional de San Juan; José A. Ambrosetti of the Instituto Argentino Zonas Aridas, Mendoza; Emilio Maury of the Museo Argentino de Ciencias Naturales, Buenos Aires; and Alberto Veloso of the Departamento Genética, Universidad de Chile, Santiago, for their generous help during the field research and their complementary study of samples of rocks, plants and animals used in my biogeographical research in the Pie de Palo massif.

\section{Literature Cited}

Caminos, R. 1979. Sierras pampeanas noroccidentales: Salta, Tucumán, Catamarca, La Rioja y San Juan. In Acad. Nac. Cien. Cordoba, Segundo Simpósio de Geología Regional Argentina 1:225-291.

CEI, J. M. 1973. Herpetología Patagonica. VII. Notas ecológicas y morfológicas sobre Liolaemus bibroni y L. boulengeri (Sauria, Iguanidae). Physis 32:459-469.

- 1980a. New endemic iguanid lizards from the Famatina mountains of western Argentina. J. Herpetol. 14:57-64.

- 1980b. Nota preliminar sobre la fisonomia faunistica y biogeográfica de la Sierra Pie de Palo, Provincia de San Juan, Argentina. História Natural. 1:137-140.

DonOSo BARros, R. 1966. Reptiles de Chile. Santiago, Univ. Chile. 458 pp.

Accepted: 3 Sept. 1981. 